carbohydrate laboratories for their original data and convert all these data in one standardized format. It is doubtful if all laboratories are able and willing to donate their data to such a project. Furthermore, a large number of compounds published show bad quality ${ }^{1} \mathrm{H}-\mathrm{NMR}$ spectra, due to a low amount of material, or the presence of impurities. In other cases carbohydrate chains could not be separated completely from each other, consequently resulting in spectra of mixtures. For the majority of published oligosaccharides, the low amount of carbohydrate material inhibits the recording of ${ }^{13} \mathrm{C}-\mathrm{NMR}$ spectra. Another approach would be to record new spectra from all known complex carbohydrates. This would by no means be easy as a lot of compounds, due to a variety of reasons, are no longer available. Dr. Yamagata suggested that all compounds should be synthesized, in order to provide the carbohydrate community with a set of reference compounds. Even if it would be possible to synthesize the larger mass oligosaccharides, it would be an extremely expensive and time-consuming project. In both cases the construction of such a database is an enormous task, which cannot be undertaken by a single laboratory.

Currently, the most practical approach is to collect NMR tables from literature, as the NMR features of hundreds of carbohydrate structures have been published. Fortunately, the published ${ }^{1} \mathrm{H}$-NMR tables contain all the information that is needed for the unambiguous assignment of complex carbohydrate structures. The tables have to be normalized, e.g. give all ppm values relative to one reference, and combined with carbohydrate structures and literature references. The logical way to do this is to utilize the efforts that have already been made in this field by CarbBank. In fact, our laboratory is undertaking this project at this moment and we hope to make the result available in the near future.
を提供してくれるかとうか不明である。更に重要なことは、今 迄に発表されているNMRデータの多くは、湘定する物質が少な すぎるかるいは不純物を含む為に、質が悪いということであ る。ある場合には、二種以上の糖鎖が完全に分離されないまま で、従って混合物のNMRスペクトルであったりする。今までに 発表された多くのオリコ榶では、測定に供する試料が少なすぎ る為に ${ }^{13} \mathrm{C}-\mathrm{NMR}$ 測定することができない。他の方法は、既に 報告された桾鎖を用いてNMRスペクトルを記録し直すことであ ろう。しかしこれは、既に報告された糖鎖の多くが様々な理由 でもう入手できないので、現実的ではない。山形博士は、糖鎖 の研究社会のために標準物質となるよう既知のすべての糖鎖を 合成したらとうかと提案している。多数のオリコ榶を合成する ことがでたとしても、それは大変高価なそして時間のかかる プロジクトとなろう。どちらの場合もこのようなデータベー スの棈築は大変な手間であり、一研究室では遂行できるもので はない。

現在のところ最も現実的なアプローチは、数百に及ぶ楛鎖 構造のNMRデータが発表されているので文献からNMRデータ表 を集めることである。幸いに、公表された1H-NMRデータ表は 榶鎖構造を絶対確実に同定するのに必要なすべての情報を含ん でいる。このデータ表は、標準化のためにすべてのppmを1つ の標準物質に対する相対値で表わし、それを糖鎖棈造のとの部 分と対応するか、そしてさらに出典も示す必要がある。理性的 に考えれば、これを実現するには䙓合榶質研究の領域ではCarbBankにより既に払われている努力を利用することである。実 際、私の研究室ではこのブロジェクトを開始していて、もうす ぐその䊅果を諸研究者が利用できるようになることを願ってい ろ。

\section{三菱化成生命科学研究所 細胞認識研究部}

山形 達也 訳

\title{
References
}

1. Bot, D. S. M., Cleij, P., van 't Klooster, H. J., van Halbeek, H., Veldink, G. A. and Vliegenthart, J. F. G. (1988), J. Chemometrics 2, 11-27

2. Jansson, P. E., Kenne, L., and Widmalm, G. (1989) Carbohydr. Res. 193, 322-325

3. Hounsell, E. F., and Wright,D. J. (1990) Carbohydr. Res. 205, 19-29.

4. Meyer, B., Hansen, T., Nute, D., Albersheim, P., Darvill, A., York, W., and Sellers, J. (1991) Science 251, 542-544. 
carbohydrate laboratories for their original data and convert all these data in one standardized format. It is doubtful if all laboratories are able and willing to donate their data to such a project. Furthermore, a large number of compounds published show bad quality ${ }^{1} \mathrm{H}-\mathrm{NMR}$ spectra, due to a low amount of material, or the presence of impurities. In other cases carbohydrate chains could not be separated completely from each other, consequently resulting in spectra of mixtures. For the majority of published oligosaccharides, the low amount of carbohydrate material inhibits the recording of ${ }^{13} \mathrm{C}-\mathrm{NMR}$ spectra. Another approach would be to record new spectra from all known complex carbohydrates. This would by no means be easy as a lot of compounds, due to a variety of reasons, are no longer available. Dr. Yamagata suggested that all compounds should be synthesized, in order to provide the carbohydrate community with a set of reference compounds. Even if it would be possible to synthesize the larger mass oligosaccharides, it would be an extremely expensive and time-consuming project. In both cases the construction of such a database is an enormous task, which cannot be undertaken by a single laboratory.

Currently, the most practical approach is to collect NMR tables from literature, as the NMR features of hundreds of carbohydrate structures have been published. Fortunately, the published ${ }^{1} \mathrm{H}$-NMR tables contain all the information that is needed for the unambiguous assignment of complex carbohydrate structures. The tables have to be normalized, e.g. give all ppm values relative to one reference, and combined with carbohydrate structures and literature references. The logical way to do this is to utilize the efforts that have already been made in this field by CarbBank. In fact, our laboratory is undertaking this project at this moment and we hope to make the result available in the near future.
を提供してくれるかとうか不明である。更に重要なことは、今 迄に発表されているNMRデータの多くは、湘定する物質が少な すぎるかるいは不純物を含む為に、質が悪いということであ る。ある場合には、二種以上の糖鎖が完全に分離されないまま で、従って混合物のNMRスペクトルであったりする。今までに 発表された多くのオリコ榶では、測定に供する試料が少なすぎ る為に ${ }^{13} \mathrm{C}-\mathrm{NMR}$ 測定することができない。他の方法は、既に 報告された桾鎖を用いてNMRスペクトルを記録し直すことであ ろう。しかしこれは、既に報告された糖鎖の多くが様々な理由 でもう入手できないので、現実的ではない。山形博士は、糖鎖 の研究社会のために標準物質となるよう既知のすべての糖鎖を 合成したらとうかと提案している。多数のオリコ榶を合成する ことがでたとしても、それは大変高価なそして時間のかかる プロジクトとなろう。どちらの場合もこのようなデータベー スの棈築は大変な手間であり、一研究室では遂行できるもので はない。

現在のところ最も現実的なアプローチは、数百に及ぶ楛鎖 構造のNMRデータが発表されているので文献からNMRデータ表 を集めることである。幸いに、公表された1H-NMRデータ表は 榶鎖構造を絶対確実に同定するのに必要なすべての情報を含ん でいる。このデータ表は、標準化のためにすべてのppmを1つ の標準物質に対する相対値で表わし、それを糖鎖棈造のとの部 分と対応するか、そしてさらに出典も示す必要がある。理性的 に考えれば、これを実現するには䙓合榶質研究の領域ではCarbBankにより既に払われている努力を利用することである。実 際、私の研究室ではこのブロジェクトを開始していて、もうす ぐその䊅果を諸研究者が利用できるようになることを願ってい ろ。

\section{三菱化成生命科学研究所 細胞認識研究部}

山形 達也 訳

\section{References}

1. Bot, D. S. M., Cleij, P., van 't Klooster, H. J., van Halbeek, H., Veldink, G. A. and Vliegenthart, J. F. G. (1988), J. Chemometrics 2, 11-27

2. Jansson, P. E., Kenne, L., and Widmalm, G. (1989) Carbohydr. Res. 193, 322-325

3. Hounsell, E. F., and Wright,D. J. (1990) Carbohydr. Res. 205, 19-29.

4. Meyer, B., Hansen, T., Nute, D., Albersheim, P., Darvill, A., York, W., and Sellers, J. (1991) Science 251, 542-544. 